\title{
PROMOTING INTRA-FIRM TRANSFER OF KNOWLEDGE THROUGH COMPETITION AND SHARING
}

\section{A Field Study*}

\author{
Johnny Jermias
}

This paper examines three main concerns about intra-firm transfer on knowledge in the management accounting and strategic management literature: the ability of real-world organizations to learn productively, the levels of aggregation in which the productive learning occurs, and the types of management interventions that are both desirable and productive. Based on a field study conducted in several business units of a multinational corporation, this paper reports how management makes conscious and systematic efforts to transform ideas from the best practice within the company as well as from its competitors.

The company uses Management By Olympic Systems to accelerate learning through competition and sharing. The system utilizes Olympic principles and integrates individual and team concepts to achieve the Olympic targets. A broad range of Olympic targets in terms offinancial and non-financial linked to the company's incentive systems is used to improve business operations, to motivate managers and employees, and to meet stakeholders' expectations.

Keywords: financial and non-financial measures; Olympic system; organizational learning; transfer of knowledge

\footnotetext{
* I gratefully acknowledge the comments made by Theresa Libby, Aloysius Lui, and Glenn Dill, as well as the anonymous reviewers of this journal. The paper has further benefited from the views of participants at the 2002 European Applied Business Research Conference, Rothenburg, Germany.
} 


\section{Introduction}

Over the last two decades, there is a growing interest in the literature that pays serious attention to the ability of organizations to their knowledge internally as well as to learn from their competitors. Many believe that for an organization to survive, its rate of learning must be equal to or greater than the rate of change in its environment (see for example Garvin 2000; Revans 1982). Although the literature on organizational learning takes many forms, the underlying concepts are broadly shared. These concepts include the propensity to experiment, ability to learn from mistakes, avoidance of stability traps, willingness to take risks, ability to identify and transfer best practices, inquiry orientation, and readiness to rethink means and ends (e.g. Garrat 2000; Argyris 1999; Lassey 1998; Szulanski 1996).

The publication of The Fifth Discipline (Senge 1996) put much impetus behind the learning organization idea. Organizations start to realize that the development of conscious and systematic efforts to accelerate learning is the only way to sustain their existence in the knowledgebased economy. Researchers and practitioners have focused their investigation of organizational learning on various aspects. Garrat (2000), for example, argues that organizational learning is the ability of individuals in the organization to sense and respond to the changes in the external and internal worlds of the organization to ensure the survival and development of the energy niches, which support it. Garvin (2000), on the other hand, emphasizes the idea of systematic experimentation movement from superficial knowledge to deep understanding, comprehensive frameworks for the evaluation of progress and the opening up of boundaries to stimulate the exchange of ideas. Similarly, Boisot (1998), investigates the process of organizational knowledge creation and distribution which is described as the process of moving from uncodified and undiffused knowledge into some form of intellectual property (codified knowledge) with the purpose of transferring it within the firm or selling it to the outside world.

Despite the growing interest in the topic of organizational learning, the normative and prescriptive literature (Garratt 2000; Argyris 1999; Khanna et al. 1998; Szulanski 1996) suggests there are three main concerns in this literature: the ability of real-world organizations to learn productively, the levels of aggregation in which the productive learning occurs, and the types of management interventions that are both desirable and productive. ${ }^{1}$

This paper reports the findings of a field study of a multinational corporation in which the management make a conscious and systematic efforts to transform ideas brought from both external worlds and the best practice within the firm to promote continuous learning in the organization. In 1997, the company introduced a new management system called Management By Olympic Systems (MBOS). The system promotes learning through competition and sharing with the ultimate goal to collectively break the "Olympic records." The Olympic records (i.e., targets) are set at various level of the organization. A broad range of targets in terms of both financial and non-financial linked to performance measurement and incentive systems is used to motivate managers and

\footnotetext{
${ }^{1}$ For an extensive review of literature on organizational learning, please consult Argyris (1999), On Organizational Learning, Second Edition, Blackwell.
} 
Jermias - Promoting Intra-Firm Transfer of Knowledge through...

employees, to improve business operations and to meet stakeholders' expectations.

The remainder of the paper is organized as follows. The next section contains the background theory and a review of the related literature. The third section discusses the field study conducted in a multinational corporation. The final section presents a discussion of the major findings, the limitation, and the implications for future research and practice.

\section{Theoretical Background and Related literature}

Argyris (1999) proposes the singleloop and double-loop learning model to define the conditions under which organizational learning takes place. The single loop learning occurs when there is a match between intentions and outcomes or when mismatches are corrected by changing actions. On the other hand, the doubleloop learning occurs when mismatches between intentions and outcomes are corrected by changing both the governing variables $^{2}$ and the actions. He suggests that all organizations should experience both single- and double-loop learning to survive. The single-loop learning helps organizations to get routine and repetitive jobs done while the double-loop learning helps organizations to deal with more complex and ill-structure issues.

In a similar vein, Garrat (2000) argues that organizations can only become simultaneously effective and efficient if there is conscious and continuous efforts from the leaders who direct the organizations (strategic learning), the staff who deliver the products or services (operational learning) and the external world in which the organizations exist (policy learning). He suggests that there should be a systematic organizational process that governs learning activities. The learning activities should be valued and be communicated throughout the organizations with the ultimate goal to move people from unconscious incompetence to conscious competence. $^{3}$

One of the most important and widespread practical organizational learning issues that have attracted widespread attention is the ability of organizations to identify and transfer the best practices within an organization and between organizations. Such practices are seen as important drivers to organizations' performance(e.g. March et al. 1991; Grant 1991; Prahalad and Hamel 1990; Argyris and Schon 1978).

Prahalad and Hamel (1990), for example, argue that organizations that use fact based management methods such as Total Quality Management, Benchmarking, and Process Reengineering should use their detailed performance data to compare the performance of their units along relevant operational or procedural dimensions. Based on the comparisons, organizations should be able to identify and transfer the best practices within the organizations to improve internal knowledge utilization. Since internal transfer of knowledge is less hindered by confidentiality and legal issues, one might expect

\footnotetext{
${ }^{2}$ The governing variables are those that drive and guide individuals' actions in organizations and can be inferred by observing the actions of individuals in the organizations. These variables are not the underlying beliefs or values people espouse (Argyris 1999: 68).

${ }^{3}$ Unconscious incompetence is a condition where people do not realize that they do not have the necessary attitudes, knowledge and skills to do their job while conscious competent is a condition where people are competent to do their job and are able to share their knowledge with others (Garrat 2000: 88-89).
} 
that such transfers could be faster and less complicated.

Some studies report, however, that significant performance gap among units within an organization is often found (Szulanski 1996; Kerwin and Woodruff 1992; Chew et al. 1990). Szulanski (1996) for example, found that performance gap of comparable units within a company can be up to 10:1. Performance gaps of 200300 percent are typical findings in internal benchmarking efforts (Xerox 1992; Zander and Kogut 1995). Studies about the transfer of best practices between organizations (e.g. Inkpen 1995; Levinthal and March 1993) report similar results.

Garrat (2000), argues that the inability of organizations to learn productively is often due to the fact that much managerial and business thinking is still locked into the application of only hard knowledge and unemotional, analytical/quantitative methods which consciously exclude the importance of people and their leaning in their organizations. As Argyris (1999) correctly asserts, however, organizational learning should be a conscious and systematic efforts by management to promote learning of individuals who happen to function in an organizational setting.

Some researchers have investigated the motivational factors that inhibit the successful transfer of knowledge (e.g. Goold et al. 1994; Porter 1985). They argue that the key of successful learning is motivation, because it provides the energy that drives forward a learning organization. Yet, motivation may be lacking when people are asked to learn something that does not particularly interest them, have little or no control or choice over and lack adequate support, respect and encouragement. To motivate people to take part in the learning activities, the learning opportunities should be seen as relevant to the needs of the learner, challenging, and recognized by people in the organization. Porter (1985) proposes that unless organizations consider the motivational factors underlying individuals' willingness to participate in the learning activities, it will be extremely difficult to get business units to engage in the learning activities.

It has long been recognized in the literature that people's motivation to pursue an action is a function of the valence (perceived value) of the reward and the expectancy of achieving that reward (e.g. Pinder 1984; Porter and Lawler 1968). Higher motivation is associated with desirable reward and greater perceived likelihood of achieving that reward. Motivation, therefore, has a positive correlation with efforts to achieve the reward and, in turn, a better performance.

Managers and employees will be motivated to participate in the learning activities if they perceive that those activities are rewarding, the reward is meaningful, they have the ability to achieve the reward, and the probability to get the reward is high when all the necessary requirements are met. Companies usually link the extrinsic rewards with some targets to be achieved. The main purpose of setting targets is to motivate employees and to coordinate efforts (Garrison et al. 2001). To be motivational, targets should be linked to organizational performance evaluation and compensation system (Hopwood 1972) and be accepted by managers and employees as their own personal targets (Drury 1997).

A number of studies have shown that acceptance of the targets as personal goals can be increased through participation in the target setting process (e.g. Libby 1999; Kren 1992). Participation means that managers and employees are able to influence the figures that make up to their targets 
Jermias - Promoting Intra-Firm Transfer of Knowledge through...

rather than being forced to accept the proposed target.

By accepting the targets as their personal objective, managers and employees will be committed to achieve the target. Commitment to a target has been found as the most important determinant of performance (e.g. Northcraft and Neale 1990; Steers 1977). Commitment to a target can be defined as a determination to try for a target and an unwillingness to abandon or lower a target once it has been accepted (Kren 1992). In addition, targets can direct people's attention and motivate people to work hard, to persist longer, and to formulate a better strategy to direct their effort toward achieving the target.

\section{The Company}

ABC Corp. is one of the largest paper producing companies in the world and an important player in view of its global presence on the market. The company is listed in New York Stock Exchange and has manufacturing units in Australia, Japan, China, Indonesia, the Middle East, and several other Asian countries. The company also has a significant market share in the United States, Europe, Australia, the Middle East and Asia.

The field study was conducted in 1998-1999. The main research questions used to guide the study are: Do real world organizations learn productively? At what level of organizations does the productive learning occur? What types of management interventions are both desirable and productive? What motivational factors are considered important in the learning activities? What is the role of financial and non-financial performance measures in the learning activities?

\section{Management By Olympic System (MBOS)}

Management of $\mathrm{ABC}$ Corp ${ }^{4}$ utilizes Olympic principles to manage the company. As in the Olympic games, competition is the most important element of the system. Management believes that the spirit of competition will generate extra energy for mangers and employees to perform at their best. Different leagues were formed to facilitate "apple-to-apple" comparisons. Managers and employees consider themselves as athletes competing each other individually as well as collectively in a group to achieve their own Olympic target and, in turn, the company's Olympic target. To promote healthy competitions and to increase motivation, the company uses transparent rules and fair evaluation in all competitions and links rewards and recognition with the employees' performance.

The major difference with the Olympic games, however, is that achieving individual or team Olympic target is not the end of itself but is a vehicle to realize the common goal of breaking the company's Olympic targets. Since the ultimate goal is to break the company's Olympic target, cross learning through sharing the secret of success from the winning teams and also learning from the best in the world are an integral part the management system.

The system links target setting with both performance measurement and compensation systems. Following is a description of MBOS. There are four underlying principles in the system:

\footnotetext{
${ }^{4}$ The company's name is disguised at the request of its management.
} 
Gadjah Mada International Journal of Business, January 2003, Vol. 5, No. 1

Figure 1. Management by Olympic System, ABC Corp

\section{Expectation}

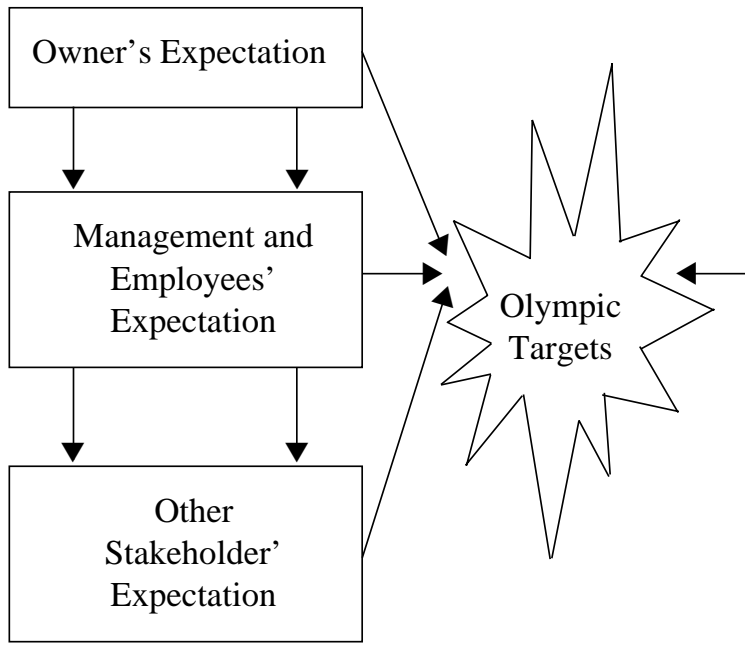

\section{Olympic Pillars}

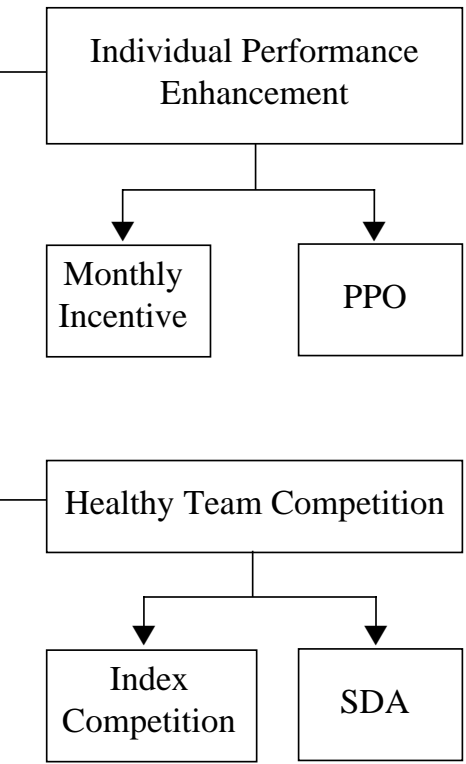

1. High aspiration targets based on Olympic spirit

2. Healthy competition with fair evaluation

3. Individual/team responsibility to meet targets

4. Performance based recognition and rewards

Figure 1 depicts the interrelationships between expectations (owners, management and employees, and other stakeholders), the Olympic targets and the Olympic pillars.

The Olympic targets represent all stakeholders' expectation. The targets are established by owners and management after taking into considerations expectations from other stakeholders such as employees, government, stock exchange, financial analysts, and society.

The Olympic pillars integrate individual and team concepts to achieve the
Olympic targets. The individual aspect of the system is called Individual Performance Enhancement, which consists of Monthly Incentive and Personal Performance Objective (PPO). The team aspect is called Healthy Team Competition, which consists of Index Competition and Skill Development Activities (SDA). All the elements in the system are aimed toward the achievement of the company's Olympic targets.

\section{The Olympic Targets}

At the beginning of each year, toplevel management gets together to determine the Olympic targets for the particular year. The targets are considered by most people to be difficult. The process of setting the target starts with the spirit to compete against the best in the world. The performance of the best company in the world in the same industry is used as a 
Jermias -Promoting Intra-Firm Transfer of Knowledge through...

benchmark to set the targets. The final targets, however, are higher than the benchmark company. For the company as a whole, the target is stated in financial terms. That is the Return on Capital Employed (ROCE) for the year (target net income divided by capital employed during the period). ABC Corp. defines the capital employed as the sum of net fixed assets and working capital (inventory plus account receivable minus account payable).

At the divisional level, the target is broken down into five key levers: sales revenue, operating cost, finance, adminis- trative, and selling (PAS) expenses, working capital, and fixed assets employed for each division. These targets are further be broken down into measures that best reflect the performance at the lower level of the organization. Figure 2 provides examples of the Olympic targets at different level of the organization. The head of each unit is responsible for the target of her unit. However, each individual within the unit (up to junior managers) has a responsibility for a part of the overall target of the unit. The individual target will be shown in his or her Personal Performance Objective (PPO). Employees in the worker lev-

Figure 2. Olympic Target at Different Organizational Level

\section{Organizational Level \\ Olimpic target}

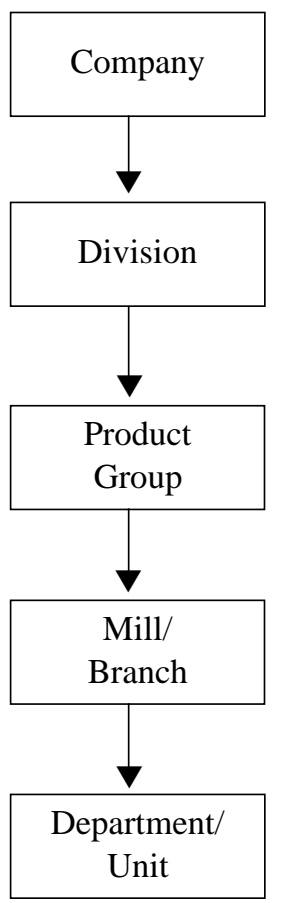

- Top management set the Olympic target based on their expectation (in terms of percentage of $\mathrm{ROCE}^{*}$ )

- The company's Olympic target is broken down into divisional target in terms of net profit and capital employed

- The divisional targets are allocated to each product group in terms of selling price, variable cost, sales and production volume, $\mathrm{PAS}^{* *}$, and working capital

- Each mill/branch is responsible to meet the target of production volume, variable cost, production fixed costs, and working capital

- Departmental/unit targets reflect the contribution expected to be made by the department/unit such as zero damage in the shipping department

*ROCE: Return On Capital Employed

**PAS: P= Production Fixed Costs; A= Administrative Expenses; $\mathrm{S}=$ Selling Expenses 
els are grouped together to support their respective managers achieving their target.

\section{The Olympic Pillars}

The pillars for achieving the Olympic target use both individual and team aspects to motivate managers and employees. Individual Performance Enhancement, which consists of PPO (Personal Performance Objective) and Monthly Incentive, is used to motivate individuals to improve their performance. On the other hand, Healthy Team Competition, which consists of Index Competition and SDA (Skill Development Activities), is aimed at promoting collective learning and sharing.

\section{Personal Performance Objective (PPO)}

Each individual in the junior management level and above is responsible for his or her target set at the beginning of each year. The target reflects contribution expected from each individual during the period. The target is set in terms of financial and non-financial (examples of individual targets in various departments see Table 1).

Junior managers and above are evaluated regularly on their achievement of the targets. Besides the quantifiable target (called KPI: key performance indicators) outlined in their PPO, managers are also being evaluated on qualitative criteria. Following are the criteria and weight (in percentage) used in the evaluation process: KPI (50\%), strategic thinking (10\%), leadership (20\%), management innovation (10\%), and teamwork (10\%).

The company uses a full circle evaluation process involving superiors, peer, and subordinates. KPI, strategic thinking and management innovation are evaluated by superiors $(80 \%)$ and peers $(20 \%)$. Leadership is evaluated by superiors $(50 \%)$, peers $(20 \%)$ and subordinates $(30 \%)$. Teamwork is evaluated by superiors $(50 \%)$ and peers $(50 \%)$.

The manager's performance measure can be summarized as Equation 1:

$$
\begin{gathered}
\text { Score }_{1}=.5\left\{.8 \frac{1}{\mathrm{~N}} \sum_{\mathrm{j}=1}^{\mathrm{N}} \mathrm{A}_{\mathrm{ij}}+.2 \frac{1}{\mathrm{~N}} \sum_{\mathrm{k}=1}^{\mathrm{N}} \mathrm{A}_{\mathrm{ik}}\right\}+ \\
.1\left\{.8 \frac{1}{\mathrm{~N}} \sum_{\mathrm{j}=1}^{\mathrm{N}} \mathrm{B}_{\mathrm{ij}}+.2 \frac{1}{\mathrm{~N}} \sum_{\mathrm{k}=1}^{\mathrm{N}} \mathrm{B}_{\mathrm{ik}}\right\}+ \\
.2\left\{.8 \frac{1}{\mathrm{~N}} \sum_{\mathrm{j}=1}^{\mathrm{N}} \mathrm{C}_{\mathrm{ij}}+.2 \frac{1}{\mathrm{~N}} \sum_{\mathrm{k}=1}^{\mathrm{N}} \mathrm{C}_{\mathrm{ik}}\right\}+ \\
.1\left\{.5 \frac{1}{\mathrm{~N}} \sum_{\mathrm{j}=1}^{\mathrm{N}} \mathrm{D}_{\mathrm{ij}}+.2 \frac{1}{\mathrm{~N}} \sum_{\mathrm{k}=1}^{\mathrm{N}} \mathrm{D}_{\mathrm{ik}}+\right. \\
\left..3 \frac{1}{\mathrm{~N}} \sum_{\mathrm{l}=1}^{\mathrm{N}} \mathrm{D}_{\mathrm{il}}\right\}+.1\left\{.5 \frac{1}{\mathrm{~N}}_{\mathrm{j}=1}^{\mathrm{N}} \mathrm{E}_{\mathrm{ij}}+\right. \\
\left..5 \frac{1}{\mathrm{~N}} \sum_{\mathrm{k}=1}^{\mathrm{N}} \mathrm{E}_{\mathrm{ik}}\right\}
\end{gathered}
$$

\begin{tabular}{|c|c|c|}
\hline Branch & Sales & Purchasing \\
\hline - Production volume & - Sales Volume & - Cost efficiency \\
\hline - Production quality & - Number of claim & - Internal customer satisfaction \\
\hline - Raw material efficiency & - Account receivable & - On time delivery \\
\hline - Inventory level & - Market share & - Order lead time \\
\hline - Machine efficiency & - Selling price & - Quality of goods \\
\hline
\end{tabular}

where,

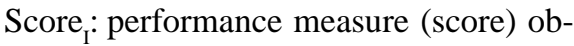
tained by manager $i$

\section{Table 1. Individual Targets in Various Departments}

22 
Jermias -Promoting Intra-Firm Transfer of Knowledge through...

$\mathrm{A}_{\mathrm{ij}}$ : KPI score for manager $i$ given by superior $j$,

$\mathrm{B}_{\mathrm{ij}}$ : Strategic thinking score for manager $i$ given by superior $j$,

$\mathrm{C}_{\mathrm{ij}}$ : Management innovation score for manager $i$ given by superior $j$,

$\mathrm{D}_{\mathrm{ij}}$ : Leadership score for manager $i$ given by superior $j$,

$\mathrm{E}_{\mathrm{ij}}$ : Teamwork score for manager $i$ given by superior $j$,

$\mathrm{A}_{\mathrm{ik}}:$ KPI score for manager $i$ given by peer $k$,

$\mathrm{B}_{\mathrm{ik}}$ : Strategic thinking score for manager $i$ given by peer $k$,

$\mathrm{C}_{\mathrm{ik}}$ : Management innovation score for manager $i$ given by peer $k$,

$\mathrm{D}_{\mathrm{ik}}$ : Leadership score for manager $i$ given by peer $k$,

$\mathrm{E}_{\mathrm{ik}}$ : Teamwork score for manager $i$ given by peer $k$,

$\mathrm{D}_{\mathrm{il}}$ : Leadership score for manager $i$ given by subordinate $l$.

The decimal numbers are parameters set by management representing the weight of each criteria and each evaluator. The evaluation process is conducted quarterly. To obtain a score from their peers, managers are grouped into several peer groups. Every manager then presents their target and achievement and each member of the peer group will score the presenter along the five criteria mentioned above. The average score an individual obtains from his or her peer group will contribute to the final score of the individual for the specific quarter.

The score from superiors and subordinates are obtained from the evaluation sheet distributed to the manager's immediate superiors and subordinates. Superiors will evaluate their immediate subordinate (managers) on all the five criteria while immediate subordinates of the managers will evaluate only on leadership criteria. The final scores from superiors, peers,
Table 2. Final Score

\begin{tabular}{cc}
\hline Category & $\begin{array}{c}\text { Rank Based } \\
\text { on Final Score }\end{array}$ \\
A & Top 20\% \\
B & Next 20\% \\
C & Next 40\% \\
D & Bottom 20\% \\
\hline
\end{tabular}

and subordinates are calculated to determine the rank of each manager (Table 2).

The rank is linked to company's compensation system. In the short term, the ranking will determine a portion of the manager's take home pay in form of monthly incentive. In the long term, the ranking will be used for job promotion and salary increment.

\section{Monthly Incentive}

The company compensates its employees on the combination of a fixed portion (basic salary and other fixed allowance (e.g. allowance for education and work experience) and a variable portion that consists of overtime/commission and monthly incentive. The monthly incentive is a bonus that varies according to the performance of both an individual and his or her department. The system allows the company to evaluate and to give feedback to its employee more frequently based on their ongoing performance.

The ranking of the managers obtained from the PPO evaluation and their respective departmental performance will be used to determine their monthly incentive. Employees at levels below junior managers will follow the rank obtained by their respective managers.

The departmental/unit performance is determined monthly based on the performance of each department/unit relative to its target and also relative to other de- 
Gadjah Mada International Journal of Business, January 2003, Vol. 5, No. 1

Table 3. Monthly Incentive Calculation

\begin{tabular}{|c|c|c|c|c|}
\hline \multirow[b]{2}{*}{ Department } & \multicolumn{4}{|c|}{ Individual } \\
\hline & A & B & C & D \\
\hline A & $100 \%$ & $80 \%$ & $40 \%$ & $0 \%$ \\
\hline B & $80 \%$ & $64 \%$ & $32 \%$ & $0 \%$ \\
\hline C & $40 \%$ & $32 \%$ & $16 \%$ & $0 \%$ \\
\hline D & $0 \%$ & $0 \%$ & $0 \%$ & $0 \%$ \\
\hline
\end{tabular}

partments'/units' performance. Therefore, departmental/unit performance indicates how well all individuals in the department/ unit work as a team. Table 3 shows the computation of the monthly incentive.

As illustrated in the table, individuals' monthly incentive depends on both her performance (represented by his or her ranking in the PPO evaluation) and his or her department's performance. For example, individual $X$ obtains a $B$ rank while her department was ranked $A$. Then, her monthly incentive will be 80 percent $(80 \%$ $\mathrm{x} 100 \%$ ) of his or her basic salary. On the other hand, if individual $Y$ obtains a $B$ rank while his or her department was ranked $D$, he or she will receive 0 monthly incentives (and all employees in the department will not receive any monthly incentive). It is clear that monthly incentive promotes both individual and group (department/unit) performance.

The total monthly take home pay received by each individual can be summarized as Equation 2:

$$
\mathrm{Tp}_{\mathrm{i}}=\mathrm{S}_{\mathrm{i}}+\mathrm{FA}_{\mathrm{i}}+\mathrm{OT}_{\mathrm{i}}+\left(\mathrm{IR}_{\mathrm{i}} \times \mathrm{DR}_{\mathrm{i}}\right) \mathrm{S}_{\mathrm{i}}
$$

where,

$\mathrm{TP}_{\mathrm{i}}$ : Monthly take hope pay of individual $i$

$\mathrm{S}_{\mathrm{i}} \quad$ : Basic salary of individual $i$
$\mathrm{FA}_{i}$ : Fixed allowance of individual $i$

$\mathrm{OT}_{\mathrm{i}}$ : Overtime incentive of individual $i$

$\mathrm{IR}_{\mathrm{i}}$ : Ranking of individual $i$ obtained from PPO process

$\mathrm{DR}_{i}$ : Ranking of individual $i$ 's department relative to other departments

\section{Index Competition}

Index competition is designed to encourage performance improvements through competition. Competition stimulates people to work harder, persist longer, and formulate better strategy to be at the cutting edge of their competitors. Without competition, performance is often stagnant. Team competition accelerates the learning process among the team members and from other sources. The key objective of the index competition is to promote learning culture among and across teams.

Each index represents a relevant operation or procedure in the company. Teams benchmark each other on indices that can be compared "apple-to-apple". Business units with different sizes are compared by transforming the absolute value of a particular aspect into a relevant index. For example, see Table 4, machine efficiency index is obtained by taking into consideration both the machine output and its installed capacity. 
Jermias -Promoting Intra-Firm Transfer of Knowledge through...

Table 4. Indices in Different Leagues

\begin{tabular}{|c|c|}
\hline League & Index \\
\hline Forestry & $\begin{array}{l}\text { Plantation area } \\
\text { Area passing minimum QC }\end{array}$ \\
\hline Pulp & $\begin{array}{l}\text { Yield ratio } \\
\text { Capacity utilization }\end{array}$ \\
\hline Paper & $\begin{array}{l}\text { Customer zero complaint } \\
\text { Ash content }\end{array}$ \\
\hline Sales \& Marketing & $\begin{array}{l}\text { Market growth } \\
\text { Accounts receivable }\end{array}$ \\
\hline
\end{tabular}

The following guidelines are used in each index competition:

1. The elements to be compared represent performance parameters that are controllable to the teams.

2. The measurement process should be straightforward and quantifiable.

3. The evaluation process and criteria should be clearly communicated to all participants.

4. The ultimate goal of the competition is to improve performance. Negative impact of the competition should be eliminated or be kept to a minimum.

5. Cross learning events following the competition enables participants to learn from each other and to share the secret of success.

The index competition involves several stages:

1. Preparation stage (design index, set rules of the games, identify world class performance on the index, communicate across company).

2. Execution stage (launch competition, select participants, evaluate team performance, select winners).

3. Recognition and learning stage (recognize and award winners, facilitate cross learning among teams).
In an index competition, each team's performance is compared to others' based on a set of rules, which are made transparent to every team. Teams learn from the winners how to improve their performance at least to the level of best practice within company. The winner coaches other team on best practice and other aspects discussed during the competition. At the conclusion of each index competition, top management challenge the teams to continually exceed their own standards and eventually match or even exceed world best practice.

These procedures form a continuous cycle, which represent efforts by both management and employees to be the number one in the world. As in the Olympic competition, management strive to create a healthy competition environment, in which transparent process, fair evaluation, and positive mindset of all participants are put in place.

\section{Skill Development Activities (SDA)}

SDA is a team-based management tool for employees to collectively contribute ideas and efforts for resolving critical business issues. SDA uses structured approach to problem solving. The team mem- 
bers consist of management and employees from various departments (cross functional). Each SDA team has five to ten members who are either expert of the issues or have significant cross-functional experience. Each team is responsible for making real improvement by using key performance measures.

The problems to be addressed should be urgent and well defined. The overall objective of the SDA is to build a performance-based organization and to develop individual capabilities to handle critical business issues. SDA creates exciting work environment enabling the team to generate innovative ideas to improve company's performance.

The company establishes an SDA management system to motivate and help SDA teams to fully realize their potential. A department called Core V-Team (CVT) was established as a facilitator for SDA members. CVT helps SDA by providing training (e.g. problem solving techniques, communication, and project management), administrative functions (e.g. SDA registration, progress report), and event management (Olympic pre-qualification, Olympic conference, cross sharing activities).

A full cycle of SDA consists of all necessary elements in project management. The cycle begins with clear target setting, work plan, implementation, monitoring progress, and closing the SDA. Following illustrates the full cycle of an SDA.

1. Identify the gap between current achievement and the Olympic target.

2. Breakdown the gap into SDA topics until the gap is closed.

3. Form an SDA for each topic by identifying team sponsor, leader, and members.

4. Set a clear target and time horizon.

5. Start working in the team by generat- ing ideas, testing/refining ideas and evaluation.

6. Systematic evaluation of ideas in terms of ongoing profit impact, one-time effects, investment needed, and other advantages/disadvantages.

7. Implementation and tracking of key milestones and financial impact.

8. Reform SDA for possible further improvement or solving other key issues otherwise dismissed the SDA team.

SDA teams work mostly after office hours to prevent from interrupting their routine work. The company provides a small incentive for each milestones achieved by each SDA team. Competitions among SDA teams are held regularly across company. At the beginning of each year (usually in February), the best SDA teams will be selected and are eligible to participate in an Olympic conference to be held at the company's headquarter.

\section{Olympic Conference}

Each year, the company organizes an Olympic conference in which all the SDA finalists share their innovative ideas with top management, and invited guests from other companies. As in the Olympic games, it involves a long and difficult process to become an Olympic finalist. There are several preceding steps for an SDA team to be eligible for the Olympic conference.

In every unit/department, there is a monthly and quarterly competition in which the winners receive prizes and recognition from management. Toward the end of the year, there is a pre-Olympic round to select SDA team for the upcoming Olympic conference. Each unit/department will send a list of their pre-qualifier (usually the winner in the department/ unit monthly competition) to participate in the Olympic pre-qualification round to be 
Jermias - Promoting Intra-Firm Transfer of Knowledge through...

held across company. All teams participated in this pre-qualification round will receive appearance rewards. The winners receive money rewards and qualify for the Olympic final.

After all the finalists have been decided, CVT run pre-final evaluation to assess all finalists. A group of judges consists of senior management from various departments visit each SDA team and ask the team to present their activities, achievement, and other relevant issues. The judges also verify the claimed result to the beneficiaries to make sure that the SDA report is valid. The judges then score each team along four dimensions: financial impact, breakthrough ideas, sustainable improvement, and teamwork. This score is weighted $80 \%$ of the final score.

At a specified date, an Olympic conference for final competition is held. At the conference, all finalists present their activities, achievement, issues and bottleneck, and other important issues in front of the owners, top management, invited guests from other companies, and invited management/employees. After a question/answer periods, the honorary judges (mostly from the owners and distinguished guests) will score each SDA team. This score (weight $20 \%$ of the final score) will be combined with the previous scores from the judges to determine the Olympic medallists (gold, silver, and bronze). Before the winners are announced, the SDA teams participated in the Olympic conference have an opportunity to share their experience with interested participants. SDA teams with similar or related themes are grouped together in one room to share their secret of success and entertain questions from their audience. The winners will also be given opportunities to share their secret of success across the company.
At the closing ceremony, the chairman of the company will announce three winners of the Olympic competition (symbolizes the gold, silver, and bronze medallists in the Olympic games). In addition, the best innovative team in terms of its outstanding contribution to implement breakthrough ideas will also be selected. All the winners will receive a substantial amount of money, certificates of winners, and recognition from the top management. The winners are also most likely to receive job promotion in the near future.

\section{Discussion}

MBOS has been used by ABC Corp. to facilitate a learning culture in the company. The system has shown its merit even in the turbulence economic conditions experienced by companies in the Asia Pacific regions. Managing through competition has stimulated the generation of breakthrough ideas across company. Challenging targets linked to performance measurement and incentive systems have motivated managers and employees to exercise their best level of performance.

By emphasizing the importance of breakthrough ideas to do things better, MBOS is consistent with the Action Learning Model (Garratt 2000) and the DoubleLoop Organizational Learning Model (Argyris 1999). Garratt proposes that learning organizations must systematically implement the learning process by identifying crucial organizational issues, providing authority to a particular group to think and work on the issues, the willingness of the group members to share the secret of success of the project to other members in the organization, and a system to acknowledge the results of the improvement initiatives by top management. In a 
similar vein, Argyris argues that learning has not occurred until the invented solutions to problems have been produced and members in organizations learn how to implement the new ways of doing things.

Although competition among departments has promoted the learning environment in ABC Corp., efforts should be made to ensure that the primary purpose of the competition is to achieve the overall company's goal and not the departmental goals. Since each department has its own goals as well as organizational goals, it is paramount that top management should encourage every department to make sure that departmental goals are achieved in ways that will help attain the organization's goal (i.e. the Olympic target). Fail to address this issue might result in goal incongruity in terms of unwillingness to share the secret of success from the winning department to other members in the company. The reluctance to share with other members to protect their departmental competitive advantages might hinder the generation and dissemination of the new knowledge.

\section{Improvement of the Existing System}

To facilitate future improvement, the following issues need to be improved. First, the system should be linked to strategic management systems, particularly with strategy formulation and management of contracts with stakeholders (Waterhouse and Svendsen 1998). The targets should reflects expectations from all stakeholders and not be limited to those of the owners and top management. The company should identify who are the important stakeholders of the company, what are their expectations, and how to maintain a mutual relationship for the company's success. This information will then be used to determine the company strategy to achieve its business goal.

Second, the Olympic targets are often felt to be unobtainable. Although managers participate in the target setting process, they are involved in a pseudo-participation in which they are under pressure to accept the proposed targets. The proposed targets introduced by top management are a way to prevent the managers and employees to set an easy target that can be easily achieved. However, the unattainable targets do not motivate managers and employees because no matter how hard they work, they still cannot achieve the targets.

To overcome the tendency of setting easy targets and at the same time improving the motivational aspects of MBOS, a "truth inducing scheme" that links target setting, performance, and breakthrough ideas can be introduced. By linking target setting process with performance and incentive scheme, dysfunctional consequences of performance measures that motivate managers and employees to engage in behavior that is not organizationally desirable can be prevented.

Finally, as in every performancebased system, MBOS puts so much pressure on all employees. Results of every competition and regular evaluation are communicated to managers and to individuals. Although good performers usually enjoy working in this environment, excessive pressure is placed on those who obtain low rank. Since the company uses relative score in ranking the employees, there are always people in the low rank although their performance is still good. An absolute score to rank employees (e.g. score above 70 percent is considered good

${ }^{5}$ For a detail explanation, please consult Chow, Cooper, and Waller (1988). 
Jermias - Promoting Intra-Firm Transfer of Knowledge through...

performance) might reduce some of the pressure. In addition, a more personal way of communicating the results of the bad performers may alleviate some of the pressure.

\section{Barriers to implementing $\mathrm{MBOS}$}

The primary purpose of MBOS is to improve companies' performance through fair competitions and sharing of new knowledge learned in the Skilled Development Activities. Unfortunately, as often faced by new initiatives intended to improve companies' performance, several problems might be faced by companies try to adopt this system.

First, resistance from managers and employees. MBOS encourages people to learn new things continuously. Sometimes, however, people do not want to exert extra efforts necessary to learn new things and are satisfied with the status quo. Some factors that might contribute to retard or obstruct the implementation of MBOS are: lack of understanding of the need of change, fear of unknown impact of the new system, lack of trust, absent of benefit from the change, and poor approach when introducing the new system.

Second, lack of commitment from top management. To implement MBOS successfully needs time and efforts. Top management must fully understand the benefits of implementing this new system and must be committed that in the long run this system will enable the company to gain competitive advantages through its ability to outperform its competitors. It takes sometime before the fruit of this system can be harvested. Lack of commitment from top management may result in the curtailment of the implementation prematurely.
Finally, lack of absorptive and retentive capacity. MBOS can be implemented successfully only when the system can be understood, exploited, and retained by people in the organization. People may lack of absorptive capacity (Cohen and Levinthal 1990) that hinder their ability to fully realize the benefits of the new system or they may also lack of retentive capacity (Druckman and Bjork 1991) that prevent them from successfully institutionalize the utilization of the new system which, when facing with initial difficulties during the integration of the new system, may become an excuse for discontinuing its use and, when feasible, reverting to the previous status quo.

Researchers (e.g. Jermias 2001; Argyris and Kaplan 1994; Kirkpartrick 1985) propose that communication and participation to the proposed change are two effective intervention techniques to reduce and overcome the problems mentioned above. The purpose of communication is to provide some stimuli to people so that their attitude and perception toward the proposed change become more optimistic by increasing their understanding of and commitment to the proposed change, reducing confusion, diffusing dissatisfaction with the status quo and sustaining the change. The purpose of participation is to encourage people to be involved and send signals that they are valued. Through participation people also have opportunities to learn about the new system, to make choice, to develop a sense of responsibility for the new system, and also to help people formulating a shared diagnosis of what is wrong in the old system and what can and must be improved. 


\section{Conclusions}

MBOS has been used by ABC Corp. to accelerate learning throughout the company. The spirit of competition, learning, and sharing, motivate managers and employees to exert their best effort achieve their Olympic targets. The targets represent contributions that are expected to be made by each individuals. The targets are stated in both financial and non-financial. The four pillars of the Olympic systems: Personal Performance Objective (PPO, Monthly Incentives, Index Competition, and Skill Development Activities (SDA) are a combination of individual and team approaches to enhance company's performance.

Three issues worth further discussions. First, to link MBOS with key stakeholders expectations and strategic management systems. Second, to increase participation in setting the targets coupled with truth inducing reward system. $\mathrm{Fi}$ nally, to alleviate some pressure placed on managers and employees through better ranking and communication systems.

\section{References}

Argyris, C. 1999. On Organizational Learning. ( $2^{\text {nd }}$ Ed.). Oxford: Blackwell Business.

Argyris, C., and D. Schon. 1978. Organizational Learning. MA: Addison Wesley.

Argyris, C., and R.S. Kaplan. 1994. Implementing new knowledge: The case of activity based costing. Accounting Horizon 8 (3): 83-105.

Boisot, M. 1998. Knowledge Assets. Oxford University Press.

Chew, W. B., T. F. Bresnahan, and K. B. Clark. 1990. Measurement, coordination, and learning in a multi-plant network. In R. S. Kaplan (ed.): Measures for Manufacturing Excellence. Harvard Business School Press.

Chow, C.W., M.K. Hirst, and M.D. Shields. 1994. Motivating truthful subordinate reporting: An experimental investigation in a two-subordinate context. Contemporary Accounting Research 10 (2) (Spring): 699-720.

Chow, C., J. Cooper, and W. Waller. 1988. Participative budgeting: Effects of a truthinducing pay scheme and informational asymmetry on slack and performance. The Accounting Review (January): 111-122.

Cohen, W.M., and D. Levinthal. 1990. Absorptive capacity: A new perspective on learning and innovation. Administrative Science Quarterly 35 (1): 128-152.

Druckman, D., and R.A. Bjork. 1991. In the Mind's Eye: Enhancing Human Performance. Washington DC: National Academy Press.

Drury, C. 1997. Management Accounting for Business Decisions. London: International Thomson Business Press.

Garratt, B. 2000. The Learning Organization: Developing Democracy at Work. London: HarperCollins Business. 
Jermias -Promoting Intra-Firm Transfer of Knowledge through...

Garrison, R. H., E. W. Noreen, G. R. (Dick) Chesley, and R. F. Carroll. 2001. Managerial Accounting: Concepts for Planning, Control, Decision Making (4 ${ }^{\text {th }}$ Canadian Ed.). Toronto: McGraw-Hill Ryerson Ltd.

Garvin, D. A. 2000. Learning in Action: A Guide to Putting the Learning Organization to Work. Massachusetts. Boston: Harvard Business School Press.

Goold, M., A. Campbell, and M. Alexander. 1994. Corporate-Level Strategy: Creating Value in the Multi-business Company. New York: Wiley.

Grant, R. M. 1991. The resource-based theory of competitive advantage: Implications for strategy formulation. California Management Review 33: 114-135.

Holmstrom, B. 1979. Moral hazard and observability. Bell Journal of Economics 10 (Spring): 74-91.

Hopwood, A. 1972. An empirical study of the role of accounting data in performance Evaluation. Journal of Accounting Research 10 (Supplement): 156-182.

Inkpen, A. 1995. The Management of International Joint Ventures: An Organizational Learning Perspective. London: Routledge.

Jensen, M., and W. Meckling. 1976. Theory of the firm: Managerial behavior, agency costs, and ownership structure. Journal of Financial Economics 3: 305-360.

Jermias, J. 2001. Cognitive dissonance and resistance to change: The influence of commitment, confirmation, and feedback on judgment usefulness of accounting systems. Accounting, Organizations and Society 26: 141-160.

Jermias, J. 1998. Budgeting and performance: A missing link?" In Radius P: Seri Membangun Bangsa. Jakarta:_Pustaka Sinar Harapan.

Kerwin, K., and D. Woodruff. 1992. Can olds hitch its Wagon to Saturn's Star?" Business Week (November 23): p. 74.

Khanna, T., R. Gulati, and N. Nohria. 1998. The dynamics of learning alliances: competition, cooperation, and relative scope. Strategic Management Journal 19: 193-210.

Kirkpatrick, D. 1985. How to Manage Change Effectively. San Fransisco: Jossey-Bass.

Kren, L. 1992. Budgetary participation and managerial performance: The impact of information and environmental volatility. The Accounting Review: 511-526.

Lassey, P. 1998. Developing A Learning Organization. London: Kogan Page Limited.

Levinthal, D. A., and J. G. March. 1993. The myopia of learning. Strategic Management Journal 14: 95-112.

Libby, T. 1999. The influence of voice and explanation on performance in a participative budgeting setting. Accounting, Organizations and Society 24: 125-137.

March, J.G., L. S. Sproull, and M. Tamuz. 1991. Learning from samples of one or fewer. Organization Science 2: 1-13. 
Northcraft, G. B., and M. A. Neale. 1990. Organizational Behavior: A Management Challenge. The Dryden Press.

Pinder, C. C. 1984. Work Motivation. Scott, Illinois : Foresman.

Porter,L.W., and E.E.Lawler. 1968. Managerial Attitudes and Performance. Homewood, Illinois: Dorsey Press.

Porter, M. E. 1985. Competitive Advantage: Creating and Sustaining Superior Performance. New York: Free Press.

Prahalad, C. K., and G. Hamel. 1990. The core competence of the corporation. Harvard Business Review 68, (3): 79-91.

Revans, R.W. 1982. The Origin and Growth of Action Learning. Chartwell-Bratt, Bromley and Lund.

Senge, P. 1996. The Fifth Discipline. Arrow: Century.

Shavell, S. 1979. Risk sharing and incentives in the principal and agent relationship. Bell Journal of Economics 10 (1) (Spring): 55-73.

Steers, R. M. 1977. Antecedents and outcomes of organizational commitments. Administrative Science Quarterly 22: 46-56.

Szulanski, G. 1996. Exploring internal stickiness: Impediments to the transfer of best practice within the firm. Strategic Management Journal 17 (Winter Special Issue): 27-43.

Waterhouse, J., and A. Svendsen. 1998. Strategic Performance Monitoring and Management: Using Non-Financial Measures to Improve Corporate Governance. Toronto : The Canadian Institute of Chartered Accountants.

Xerox. 1992. Worldwide best practices reference guide. Worldwide Marketing Quality Officers. NY: Rochester.

Zander, U., and B. Kogut. 1995. Knowledge and the speed of the transfer and imitation of organizational capabilities: An empirical test. Organization Science 6 (1): 76-92. 